\title{
28 Research Square \\ Design and study of Solid Waste Management in Ranchi, Jharkhand
}

\author{
Ankish Aman \\ Birla Institute of Technology \\ PK Srivastava ( $\nabla$ pksrivastava@bitmesra.ac.in ) \\ Birla Institute of Technology
}

\section{Research}

Keywords:

Posted Date: June 9th, 2020

DOI: https://doi.org/10.21203/rs.3.rs-32222/v1

License: (c) (i) This work is licensed under a Creative Commons Attribution 4.0 International License. Read Full License 


\section{Abstract}

Solid waste management (SWM) have becomes a very serious concern globally. The lack of individual responsibilities as well as proper attitude and approach leads to this issue. Rapid industrialization, increase in population and further increase in standard of living and poor waste management have increased the serous health issue. Ranchi city need to be taken care by various new SWM techniques, proper management skill and adequate care the diseases and improve medical conditions. This paper deals with the proper description of the current MSWM process and the real time scenario where every individual is a source of waste creation. The effect of growing population of last ten years outcome of waste quality and quantity generated throughout these years have been discussed. It is observed that more than 4000 tons of waste per month is being generated. Researches shows that the disposal of solid waste requires 2,700,000 $\mathrm{m}^{2}$ area for the landfill up to the year 2030. Far sustainable development and effective management it is suggested that implementation of newer technologies, training of common people, and effective implementation of government policies will help to come out of these current issues.

\section{Introduction}

Today effective management of solid waste generation is one of the potential issue of developing countries. The increase in the waste throughout the year is a significant problem due to urbanization and population growth. There are several local bodies involved in the waste collection, disposal and finally processing. However the current growth of population led to improper management and processing of waste. Ranchi city is located at 85.30 east and 23.30 north to the topic of cancer, its municipal area is around $650.02 \mathrm{~km} 2$, and $653 \mathrm{~m}$ above sea level [1]. Ranchi considered as the hill station has the composite climate. Ranchi city is located in a Chota Nagpur Plateau, which has forest scenery around it. The growing population, urbanization, improper management of solid waste and lack of environmental training caused this place to its degradation, therefore the reliable waste management technology is required. Municipal solid waste (MSW) considered as trash, garbage and rubbish in United States and Britain. The composition of solid waste can be categorized from its processing properties and different states. Municipality waste also described as a domestic waste released from houses, hospitals, markets, and many service providing sectors.

The waste is categorized as Biodegradable waste, which can undergo degradation by microorganisms or microbes; Recyclable waste such as paper polythene which can withstand the recycling process; Construction waste from the construction site like debris rocks; Electrical and electronic waste such as light bulbs, batteries; Extra composite wastes such as leather clothes, plastic toys; Hazardous waste, which are mostly from the chemical industry converted into spray cans, tires, and fertilizers and; Toxic waste which is basically from fungicide, pesticides and herbicides. SWM from the municipality undergo treatment by recycling, composting, energy recovery and incineration. 
The generation of waste in India has increased enormously since three decades. Extensive researches are needed for the fruitful waste organization in urban India which involve by 1.3 billion individuals, produces about 1.5 lakh metric ton waste daily where only 70 percent are gathered, and rest are still in the environment. Approximately 31 million tons (48 percent) are dumped at landfill destinations [2]. CPCB (Central Pollution Control Board) in India is offering RMC (Ranchi Municipal Corporation) guidelines for gathering, transportation, and disposal of stable waste from the city. Ranchi is evaluated to make more than 400 tons of trash/waste each day. The per capita waste generation are 450-500 gm for every person/day. The promotion of public awareness, legislation, financial and economic calculations, strengthen institutional capacity and regulations enforcement and establishment of a proper sanitary landfill are considered to be principal remedial measures to ensure sound environmental maintenance.

\section{Methodology}

The study is conducted to find the status and challenges of MSWM in Ranchi. An assessment of MSWM parameter conducted through survey to find MSW age, assortment, and treatment alternatives drilled in Ranchi city. The sample of waste is weighed and through simple calculation the percentage of different waste composition is measured. The types of solid waste produced, how it is produced, overseen, disposed is studied in this article. The research was directed in Ranchi town around 35 kilometers area. The investigation manages to present difficulty to control squanders provoking irrational dumping; poor administration prompting biological defilement, the spread of diseases, land debasement, and appalling living. The RMC is spread over a zone of $652.02 \mathrm{~km} 2$ and data is accessible in the website. The examination presumes that the establishment of decentralized solid waste handling units in the city improve the formal recycling industry. The rag picker has a significant influence during the management process since they recover significant recyclable waste. The waste management system in Ranchi lacks superior sorting devices therefore the individuals ought to be instructed to understand the significance of source isolation at the first point as biodegradables, non-biodegradable, and recyclable material. Simultaneously a landfill is designed to check the waste management procedure. The ultimate aim should be to incorporate the zero-waste system therefore suggested recommendation provided that could be incorporated to reduce waste.

\subsection{Setting of the study}

Municipal solid waste management (MSWM) in Ranchi a part of eastern India is still under development. The topic of cancer passes from Ranchi district. It is capital of Jharkhand state India. Ranchi annual average temperature has increased from $31^{\circ} \mathrm{C}$ to $37^{\circ} \mathrm{C}$ within the span of last 10 years from 2009 to 2019 [1]. The population of Ranchi district is around 23 lakh people. The people work in the government organization and private sector. The city have dominant economy based on businesses in hotel, restaurant, stall, food truck, repair shop, furniture shop, automobile centre, carpentry, and other sectors. Illiteracy and unemployment are high therefore most people take up jobs as driver, cleaning service, and other low skilled job [3]. A private vehicle tempo/car run on diesel/petrol are the primary mode of the 
transportation. The research survey was done in 4 central posh locations and one slum area. Four significant posh places in Ranchi subjected for investigation are Hinoo, Ashok Nagar, Harmu, and Mahatma Gandhi Road. These places with significant shopping centre, local food stall and vendor shop are major source of waste generation. The slum area considered for study in Latma, Hatia are approx 35 kilometer of radius.

\subsection{Data Collection}

Images and information in form of data is collected from proper interaction with the municipality people. The current waste transportation details from the various locations obtained from the website. The data is appropriately incorporated in this paper through the documentation. The significant factors of waste generation are the economic activities, population growth, drain off local water bodies, improper land use and deforestation.

\subsection{Survey Procedure}

The surveys has been done through questionnaire prepared in form of systematic waste report and the study is done by consulting people about the approximate waste generation throughout the month. The questions about the current living standard was also included. The form was filled by the people who are majorly working in the municipality, local vendor, garbage collector and house owner. Through field survey it is found that dustbin at busy roads are adequate but less in significant locality having dense population. A typical photograph of bins represented in Fig. 1. The systematic waste question is filled up every day in the morning by asking questions about the significant waste generation from the locality. The approx. percentage of garbage is measured by categorizing and segregated the waste separately and then measuring in the weighting scale. The segregated waste measured is simplified in form of percentage by simple calculation. Systematic waste report questions are prepared in Hindi (local language of Ranchi) and then translated into English. Two sets of the report are ready one from the technical person and one for the local people.

Figure 1 Dustbin provided by Ranchi nagar nigam

\section{Results And Discussion}

The following data collected are simulated in the table. The report prepared is characterized into three groups that are recyclable waste, disposal waste, and other hazardous waste. One of the significant landfills in the Ranchi district is the Lohardaga landfill located $15 \mathrm{~km}$ away from Ranchi. The Lohardaga landfill is located near the Jhiri village, also termed as Jiri Sanitary Landfill. Other Sterile Landfill sites in Ranchi are Nav Kendra Bharat Jagriti, where many people work, and are the major wastes disposal area. The local people do not have any knowledge to deal with the waste management, and its framework. By visiting and inspecting, it is found that waste management is incompetent in reducing this ample amount of trash. These can be seen over the years where the local water bodies that are harmu river ultimately declined and drained, with solid waste floating all over the water bodies. The Subarnarekha River has 
dried, and formation of algae has taken place. The photograph of Harmu River and Subarnarekha River can be seen in Fig. 2(a) and 2(b).

Figure 2. (a) Dried Harmu River, Ranchi (b) Present condition of Subarnarekha River in Hinoo location, Ranchi

\subsection{Waste collection}

The waste collected from the locality with the help of the dustbin and trails are provided at each location. There is no significant data available for Ranchi regarding waste management techniques. World Bank report shows that low income countries achieve waste collection about $48 \%$ from urban areas and $26 \%$ in rural areas [4]. Ranchi comes in a class of low-income district. RMC report suggests that 912 grams per capita waste are generated from the city. Sanitary landfill is a significant waste processing way for dumping place. Most of the waste that does not fit in tractor trumpet drills are left and dumped locally. The Hinoo location have Mecon dumping ground where an organic waste converter plant is built, but it is in the non-working condition these photographs are represented in Fig. 3. Figure 4 shows the photograph of leftover dumping in Hinoo, phd Colony. From the figure, it can be seen that the waste collection trailer is entirely distorted. The survey report of monthly transportation is represented in the table. The proper survey result shows the tractor transportation and Dumper trip movement for dumping the collected waste. Total monthly waste received is also represented in the Table 1. 
Table 1

Monthly waste collection report of tractor, dumper tipper, dumper placer and total weight received in on ton.

\section{Figure Description}

Figure Dustbin provided by Ranchi nagar nigam

1

Figure (a) Dried Harmu River, Ranchi (b) Present condition of Subarnarekha River in Hinoo location, 2 Ranchi

Figure Organic waste converter in Mecon, Ranchi

3

Figure Open waste dumping in Hinoo locality, Ranchi

4

Figure (a) Transportation of waste from Ashok nagar, Ranchi (b) Waste transportation from Bit

$5 \quad$ Mesra, Ranchi (c) Waste transportation from Latma road, Ranchi

Figure (a) Google map of dumping site in the village- Jhirri Thana, Ranchi (b) The dumpsite in

6 Jhirri Thana, Ranchi

Figure Unorganized waste segregation of Ashok Nagar

7

Figure (a) Graphical weight composition percentage of solid waste (b) Overall physical

8 composition report

Figure Waste management framework

9

Figure 3 Organic waste converter in Mecon, Ranchi

Figure 4 Open waste dumping in Hinoo locality, Ranchi

\subsection{Waste transportation}

Transportation of waste is done by vehicle majorly by tractor from the main highway road and from a crowded market. For most locality the transportation of waste is either by rickshaw or trolly (light commercial vehicle). Photograph in Fig. 5(a) shows the transportation of waste from Ashok Nagar by Auto with the trailers attached. Small trucks used to carry waste from densely populated areas. In some posh location, the skip lorry is used to transport the trash from the dustbin. The photograph in Fig. 5 (b) shows the transportation of waste from BIT Mesra with the trailer attached to it. While the photograph in Fig. 5 (c) represents waste transportation from Latma road Ranchi by rickshaw. From 1st July to 1st October 2019 monthly transportation data is obtained by inspecting the trip of dumper placer, tractor, dumper tipper and dumper placer used for transportation and disposal. The overall weight received per month in Ton is calculated and tabulated in the table. This data is obtained with cooperation from RMC waste disposal in-charge and from the driver in-charge for transportation from RMC office. Average MSW carrying capacity for tractor trolley, dumper tipper and dumper placer is 1.6, 4.35, 2.3 Ton respectively. 
Monthly Weight received $=($ Average weight disposal from tractor trolley $\mathrm{X}$ number of trips $)+($ Average weight of MSW in Dumper Tripper X number of dumper tripper trip) + (Average weight of MSW in dumper placer $\mathrm{X}$ number of dumper placer trip). The Table 1 represent the simulated data in the tabular form.

Table 1 Monthly waste collection report of tractor, dumper tipper, dumper placer and total weight received in on ton.

1. (a) Transportation of waste from Ashok nagar, Ranchi

2. (b) Waste transportation from Bit, Mesra, Ranchi

3. (c) Waste transportation from Latma road, Ranchi

Figure 5: Waste collection and transportation from different places in Ranchi

1. (a) Transportation of waste from Ashok nagar, Ranchi

2. (b) Waste transportation from Bit, Mesra, Ranchi

3. (c) Waste transportation from Latma road, Ranchi

\subsection{Disposal}

Waste collected is disposed of in the dumping location. The dumping is dependent on the site condition. The disposal action is then carried forward with sanitary landfill treatment. Recycle waste, biodegradable waste, and hazardous waste that has not been separated are dumped together, which makes this dumping ground ineffective to reduce these waste. A major treatment of solid waste is achieved by segregating the waste. The advanced technique is required for separating these waste, or a proper training session should be done so that waste could be separated into a different color bin from home and from the source the waste is generated. The waste has the potential for energy production therefore effective management technique is followed. The dumpsite in Jhirri Ranchi is represented in from of google map in Fig. 6 (a) whereas 6 (b) represents the photograph of dumping site, where major waste up to 40 percent is disposed. Some of the wastes are disposed of in Mecon dumping site while remaining waste dumped locally by the unlicensed vendor. The waste without segregation are dumped altogether as shown in the photograph. The photograph of Ashok Nagar a posh location in Ranchi shows unorganized waste segregation in Fig. 7.

Figure 6 (a) Google map of dumping Site in the village- Jhirri Thana, Ranchi

(b) The dumpsite in Jhirri Thana, Ranchi

Figure 7. Unorganized waste segregation of Ashok Nagar

\subsection{Solid Waste Nature and Composition}

From the data obtained, the waste is categorized into three parts: - degradable waste, non-degradable waste, and other waste hazardous waste. The Plastics are of two type's biodegradable plastics and nonbiodegradable plastics; the biodegradable plastics are bio-based plastics, Polyhydroxyalkanoates (PHAs), 
Polylactic acid (PLA), Cellulose-based Plastics, Lignin-based polymer composites, Petroleum-based plastics, Polycaprolactone (PCL), Poly vinyl alcohol (PVA), and Polybutylene adipate terephthalate (PBAT). The non-biodegradable plastics are Polyethylene terephthalate (PET), Polyvinyl chloride (PVC), Polypropylene (PP), Low-density Polythene, and Polystyrene (PS). It is difficult to find out the category of plastics after it is mixed and dumped. A robust chemical separation technique is required to separate them. Through the survey it is found that majorly non-biodegradable plastics are used and the percentage of degradable plastics are almost negligible. The strong government action required to reduce plastics. Recently government took an initiative to ban use of plastics but still, there is wide plastic usage. The data of different waste categories are represented in the table, the survey shows the solid waste generation in Ranchi district. The sample of garbage collected from all six significant locations are weighed and categorize in different column of waste in the table. The percentage of each waste from weighing machine separated into biodegradable, recyclable waste and other waste represented in Table 2, 3,4 . The plastics and polythene are categorized in recyclable waste to simplify categorization. The survey result is obtained from different location in Ranchi and categorized into three subparts such that it can undergo effective processing. Table 5 represent data of overall waste generation along with its percentage and composition. Table 6 is percentage of physical composition and its graphical representation is shown in Fig. $8 a$ and $b$

Table 2

Biodegradable waste percentage and survey

\begin{tabular}{|lllll|}
\hline $\begin{array}{l}\text { Monthly wise } \\
\text { data }\end{array}$ & $\begin{array}{l}\text { Trip of } \\
\text { tractor }\end{array}$ & $\begin{array}{l}\text { Trip of dumper } \\
\text { tipper }\end{array}$ & $\begin{array}{l}\text { Trips of dumper } \\
\text { placer }\end{array}$ & $\begin{array}{l}\text { Overall weight } \\
\text { received monthly wise in } \\
\text { Ton }\end{array}$ \\
\hline July 1 & 1672 Trips & 27 Trips & 578 Trips & 4122.5 \\
\hline Aug 1 & 1778 Trips & 32 Trips & 854 Trips & 4313.4 \\
\hline Sep 1 & 1668 Trips & 26 Trips & 539 Trips & 4021.6 \\
\hline Oct 1 & 1680 Trips & 24 Trips & 747 Trips & 4510.5 \\
\hline
\end{tabular}


Table 3

Recyclable waste percentage and survey

\begin{tabular}{|lll|}
\hline Bio-degradable & Percentage composition (\%) & Number of respondents \\
\hline Clothes & 2.991452991 & 7 \\
\hline Leather & 1.282051282 & 3 \\
\hline Grass & 0.854700855 & 2 \\
\hline Cow dung & 0.854700855 & 2 \\
\hline Peelings & 28.20512821 & 66 \\
\hline Waste food & 16.23931624 & 38 \\
\hline Total & 50.42735043 & 118 \\
\hline
\end{tabular}

Table 4

Other waste survey and percentage (biomedical waste, hazardous waste)

\begin{tabular}{|lll}
\hline Recyclable waste & $\begin{array}{l}\text { Percentage composition } \\
(\%)\end{array}$ & Number of respondents \\
\hline Polythene & 23.93162393 & \\
\hline Bottles & 4.700854701 & \\
\hline Metals & 2.136752137 & \\
\hline Glass & 3.846153846 & \\
\hline Papers & 8.11965812 & Number of \\
\hline Total & 42.73504274 & respondents \\
\hline $\begin{array}{l}\text { Other waste (Biomedical waste, hazardous } \\
\text { waste) }\end{array}$ & $\begin{array}{l}\text { Percentage composition } \\
(\%)\end{array}$ & 3 \\
\hline Ash & 1.282051282 & 9 \\
\hline Syringe, blood cotton, tablets & 3.846153846 & 4 \\
\hline Construction debris & 1.709401709 & 16 \\
\hline Total & 6.837606838 & \\
\hline
\end{tabular}


Table 5

Overall survey report

\begin{tabular}{|llll|}
\hline S.N & Composition & Percentage composition (\%) & Number of respondents \\
\hline 1 & Polythene & 23.93162393 & 56 \\
\hline 2 & Bottles & 4.700854701 & 11 \\
\hline 3 & Clothes & 2.991452991 & 7 \\
\hline 4 & Metals & 2.136752137 & 5 \\
\hline 5 & Glass & 3.846153846 & 9 \\
\hline 6 & Leather & 1.282051282 & 3 \\
\hline 7 & Grass & 0.854700855 & 2 \\
\hline 8 & Cow dung & 0.854700855 & 2 \\
\hline 9 & Ash & 1.282051282 & 3 \\
\hline 10 & Peelings & 28.20512821 & 66 \\
\hline 11 & Syringe, blood cotton, tablets & 3.846153846 & 9 \\
\hline 12 & Construction debris & 1.709401709 & 4 \\
\hline 13 & Waste food & 16.23931624 & 38 \\
\hline 14 & Papers & 8.11965812 & 234 \\
\hline & Total & 100 & 19 \\
\hline
\end{tabular}


Table 6

Physical composition percentage

\begin{tabular}{|ll|}
\hline Physical composition & Constituent percentage (\%) \\
\hline Bio-Degradable & $50 \%$ \\
\hline Plastic, Recyclable Paper, Metal, Rubber, Glass, etc. & $43 \%$ \\
\hline Other Waste (Biomedical Waste, Hazardous Waste) & $7 \%$ \\
\hline Fig. 1 & \\
\hline Dustbin provided by Ranchi nagar nigam & \\
\hline
\end{tabular}

Fig. 2

(a) Dried Harmu River, Ranchi

(b) Present condition of Subarnarekha River in Hinoo location, Ranchi

Fig. 3

Organic waste converter in Mecon, Ranchi

Fig. 4

Open waste dumping in Hinoo locality, Ranchi

Fig. 5

(a) Transportation of waste from Ashok nagar, Ranchi

(b) Waste transportation from Bit, Mesra, Ranchi

(c) Waste transportation from Latma road, Ranchi

Figure 6

(a) Google map of dumping Site in the village- Jhirri Thana, Ranchi

(b) The dumpsite in Jhirri Thana, Ranchi

Fig. 7

Unorganized waste segregation

Fig. 8

(a) Graphical weight composition percentage of solid waste

(b) Overall physical composition report

Fig. 9

Waste management framework 
Table 2 Biodegradable waste percentage and survey

Table 3 Recyclable waste percentage and survey

Table 4 Other waste survey and percentage (biomedical waste, hazardous waste)

Table 5 Overall survey report

Table 6 Physical composition percentage

Figure 8 (a) Graphical weight composition percentage of solid waste

(b) Overall physical composition report

\section{Ranchi Per Capita Contribution \\ 4.1. Population data of Ranchi}

Ranchi became the capital of newly formed Jharkhand State in 2000 this created rapid urbanization for obtaining lively hood in a government job and private sectors or to establish a private business. The current city has populace $1,126,743$, with 46 th rank as the most prominent Indian urban city. The sex ratio of male and female are $51.4 \%$ and $48.6 \%$ with $87.68 \%$ average literacy pace.

\subsubsection{Amount of solid waste generated}

In India, 62 million tons yearly averages out to 450 grams of waste per person per day. In any case, there is a great deal of changeability in the per capita waste age in India. Day by day unit of MSW age ranges from 170 grams per person in rural communities to 620 grams per person in substantial urban areas. Given that the population in Ranchi municipality is $1,126,741$ and Ranchi district population is $2,914,253$ the average waste generation rate is $0.45-0.5 \mathrm{~kg} /$ person/day. India is a lower-middle-income country; the waste generation rate is estimated at the range of $0.4-0.5 \mathrm{~kg} /$ person/day [5].

Generation rate per person for Ranchi municipality $=$ Average ton of waste generated $/$ Population of Ranchi

From Table 1 average ton of waste generated $=4388.75$ ton $/$ day

Therefore, the amount of waste generation rate in Ranchi district is

$=(0.4 \times 1,126,741)$

$=450,696.4 \mathrm{~kg} /$ day

Amount generated per year $=(450,696.4 \mathrm{~kg} /$ day $) \times 365=164,504,186 \mathrm{~kg}$ or 164504.2 ton 


\subsection{SWM Design}

\subsubsection{Ranchi District Population}

Ranchi population in 2011 was 2,914,253 with sex ratio of male and female were 1,494,937 and $1,419,316$ respectively. In 2001 census, Ranchi had a population of 2,350,612 of which males were $1,218,830$ and remaining 1,131,782 were females [5]. Using geometric progression relationship in Eq. 1; Where;

$P_{f n}=$ anticipated future populace after $\mathrm{y}_{\mathrm{n}}$ years

$P_{i n i}=$ initial population in the base year

$\mathrm{R}_{\mathrm{t}}=$ estimated annual population growth in percentage (\%)

$y_{n}=$ number of years $(10)$

$P_{\text {fn }}=P_{\text {ini }}\left(1+R_{t} / 100\right) y_{n}$ Eq. (1)

$2,914,253=2,350,612\left(1+R_{t} / 100\right)^{10}$

$\mathrm{R}_{\mathrm{t}}=2.171$

Population after 19 years; taking 2011 to be the base year.

Therefore from Eq. (1)

$P_{\text {fn }}=P_{\text {ini }}\left(1+R_{t} / 100\right) y_{n}$

$P_{f n}=2,914,253(1+2.171 / 100)^{19}$

$P_{f n}=4,382,808.441$

Thus the population of Ranchi district $\left(\mathrm{P}_{\mathrm{fn}}\right)$ will be around 43 lakh in year 2030

\subsection{Squander age}

The squander age rate is $0.4 \mathrm{~kg} /$ individual/day [6]. This information is discovered from the world bank of low pay nation. Utilizing current populace of 2,914,253 individuals. A measure of waste produced in a year will be $(0.4 \mathrm{~kg} /$ day $\times 2,914,253) \times 365$ days $=425,480,938 \mathrm{~kg}=469,107.98$ tons

The volume of landfill space required $=[($ waste created $) /$ (thickness of waste) $]$ Eq. (2)

For squander densities (wet weight premise) of a lower centre salary nation's scope of between 375$650 \mathrm{~kg} / \mathrm{m}$. Subsequently, thinking about $650 \mathrm{~kg} / \mathrm{m}$ 
The volume of landfill space required:

$=(469,107.98 / 650) \times 1000$

$=7.217 \times 10^{5}$

\subsubsection{Required land zone}

Arranging confinement restricts the stature of the landfill to $10 \mathrm{~m}$. On the off chance the tallness is $10 \mathrm{~m}$, subsequently,

The required land zone $=$ volume of landfill space required/stature of the landfill

$=7.217 \times 105 \mathrm{~m}^{3} / 10 \mathrm{~m}=7.217 \times 10^{4} \mathrm{~m}^{2}=7.2 \mathrm{ha}$

$\left(1 \mathrm{ha}=10000 \mathrm{~m}^{2}\right)$

This worth should be expanded by about half to take into account everyday spread, street territories, and fencing.

Required territory for a long time $=7.2 \times 25 \times 1.5=270$ ha

\subsubsection{Measuring the landfill area}

270 ha $=2,700,000 \mathrm{~m}^{2}$. Take the length to be $800 \mathrm{~m}$. Subsequently, the landfill measurements are $800 \mathrm{~m}$ $\times 337.5 \mathrm{~m} \times 10 \mathrm{~m}$. Thus

$2700000 /(800 \times 10)=337.5 \mathrm{~m}$ width of landfill area.

\subsubsection{Squander Quantification}

Size of the bed is $(30 \mathrm{~m} \times 15 \mathrm{~m}) \times(2$ to $3 \mathrm{~m})$ and $(40 \mathrm{~m} \times 20 \mathrm{~m}) \times(2$ to $3 \mathrm{~m})$; Assume size of bed as (40 m $\times 20 \mathrm{~m}) \times 3 \mathrm{~m}$ (tallness $=3 \mathrm{~m}$ ); In this tallness, Waste layer $=0.8 \mathrm{~m}$; Clay layer $=0.3 \mathrm{~m}$; At that point layer of waste is three layers, $0.8 \mathrm{~m} \times 3=2.4 \mathrm{~m}$; Dirt layer is additionally 3 layers, $0.3 \mathrm{~m} \times 3=0.9$; Genuine single pit squander conveying limit, $40 \mathrm{~m} \times 20 \mathrm{~m} \times 2.4 \mathrm{~m}=1920 \mathrm{~m}^{3}$; Considering $20 \%$ of space because of incline, $2.4 \mathrm{~m} \times 12 \mathrm{~m} \times 15 \mathrm{~m}=432 \mathrm{~m}^{3}$;

$432 \mathrm{~m}^{3} / 2=216 \mathrm{~m}^{3} ;$

$1920 m^{3}-216 m^{3}=1704 m^{3}$; i.e. $1704 m^{3}$ real waste in 1 pit. ;

Removal of earth work $17 \mathrm{~m} \times 32 \mathrm{~m} \times 3.5 \mathrm{~m}=1964 \mathrm{~m}^{3}$

\section{Recommendation}


The Fig. 9 represents a flowchart or framework that could be incorporated for waste management in Ranchi City. The flowchart shows the proper waste management techniques that can be carried out to minimize and reduce the waste.

Figure 9 Waste management framework

\subsection{Waste Sorting.}

After collection the waste undergo segregation technique. The various waste segregation technique involved are as follows.

\subsubsection{By picking. -}

In the waste management process, the necessary segregation by visual inspection and picking process. The waste is picked up according to its shape and size

\subsubsection{Screening. -}

The Second stage is screening which involve transferring the waste by passing it through different holes in increasing order per stage. The action of separation carried through vibration of gauge. The more classified technique further required in different stages of separation since many different categories of waste may be of similar size.

\subsubsection{Magnetic Separation: -}

Third stage sorting done by passing the waste through the magnetic poles to remove the metallic waste components such that it can undergo recycling and deep burial.

\subsubsection{Optical Separation or sorting:-}

These are software-driven sorting techniques for separating the waste using image processing technique with the help of laser and camera. The laser and camera separate the unwanted material by comparing it with preinstalled component shape and size from the database. The ultraviolet laser light and infrared light used for inspection match the different spectrums of the waste component. The matched spectrum gives feedback for bypassing the air jets to sort the waste.

\subsubsection{Mechanical Separation: -}

Mechanical separation is a combination of both screening and magnetic separation of removing the material by action of specific gravity. The transfer of waste from one station to another takes place by conveyor belt.

\subsubsection{Floatation:-}

The waste is separated by floatation action by passing it into floatation tank after segregating it into a different bin. The waste that floats in water separated after allowing it to soak in properly while rest are 
separated differently by the action of density.

\subsubsection{Eddy current method: -}

When waste of similar size is collected, these waste can be separated by eddy current method, which separates the ferrous material from the lot bypassing the eddy current, which forms its magnetic field leading separation from the conveyor belt. The current flow in the circular loop such that waste is eliminated into a different bin [7]. This type of shorting can be done in a stepwise process; thus, the particular advance system should be produced with smart manufacturing such that these shorting processes can be carried out in one system or a closed machine. Israel has the most advanced waste shorting technique and follows zero waste concept. The recycled waste segregated undergo recycling in the plant for the recovery process. The different waste according to its properties undergo various treatment process as categorized in the flowchart.

\subsection{Biodegradable waste treatment}

The biodegradation is a process to breakdown complex compound to simpler compound these can be done by different process these are:-

\subsubsection{Composting: -}

The biological treatment which involves the degradation of organic compound into simplex form by the action of bacteria leading to the formation of humus, which add fertility to the plant's crops. These techniques in home can reduce waste therefore initiative and workshop for the compositing could create greener path towards sustainable development. The compositing is of three types:-

\subsubsection{Aerobic Composting: -}

The composting in the open area of a pit where degradation takes place in the presence of air to undergo the composting process.

\subsubsection{Anaerobic composting: -}

Composting in the absence of air by covering the waste to let anaerobic bacteria to undergo the degradation process.

\subsubsection{Vermicomposting: -}

The special types of worms used for example red and white worms to let the composting process to undergo.

\subsubsection{Biogas plant: -}

The process by which organic waste can be degraded in the digester by the action of microorganism by thermal decomposition, i.e., in the presence of temperature and pressure. Bacteria degrade organic waste in the absence of air (vacuum). Biogas is created by anaerobic assimilation with methanogen or 
anaerobic living beings, which digest material inside a shut framework, or maturation of biodegradable materials. This shut framework is called an anaerobic digester/ bio digester, or a bioreactor. Biogas principally lead to methane $\left(\mathrm{CH}_{4}\right)$, carbon dioxide $\left(\mathrm{CO}_{2}\right)$, and may have modest quantities of hydrogen sulfide $\left(\mathrm{H}_{2} \mathrm{~S}\right)$, dampness, and siloxanes. The gases methane, hydrogen, and carbon monoxide (CO) can be combusted or oxidized with oxygen. This vitality discharge permits biogas to be utilized as a fuel; it very well may be used for any warming reason, for example, cooking. It can likewise be used in a gas motor to change over the vitality in the gas to thermal energy. At the initial stage, the waste is mixed with water to make a slurry.

\subsubsection{Fermentation: -}

A metabolic process that leads to chemical changes into organic substrates by the action of enzymes in biochemistry. It can be defined as the extraction of energy from carbohydrates in the absence of air ethanol production from fermentation.

\subsubsection{Landfill: -}

The landfill is the term utilized to dump the waste in the broad area or ground to treat the waste and to remove from the environment, it also portrays the physical changes during the disposal of solid wastes and residue on the surface. Sanitary landfill requires a large facility for the disposal of MSW and operated to limit public health. The waste is to be covered daily by soil as an intent material in a scientific manner. The precautions to prevent leachate leakage into the soil and groundwater therefore it should be away from the water bodies. To meet large disposal, large landfills are required to meet the disposal need with growing population leading to an increase in the garbage content. Thus adequate $3 \mathrm{R}$ techniques should be adopted from the municipality to every community with proper initiative. Landfills require significant land demand for waste treatment. Only hazardous waste can undergo landfill rest waste can be split up under biodegradable waste and biomedical waste treatment segment.

\subsubsection{Incineration: -}

Incineration is the thermal combustion process similar to some extent to gasification, anaerobic digestion, and pyrolysis. In incineration, the waste most commonly organic or biomedical waste will undergo combustion to release flu gas and heat, which can be used for waste to energy conversion run a turbine to generate electricity directly with the gases or secondary gas. The leftover material, i.e., ash can be used to take the form of solid lumps or carried out through flu gas. This ash can also be treated in landfills. A proper air pollution control equipment is required to mitigate the growing air pollution in Ranchi. The air quality index (AQI) comes in unhealthy zone as of 19 November 2019 where the particulate matter (PM) is $172 \mathrm{AQI}$ with 2.5 (microns). Incineration plants can also be used for biomedical waste treatment of used cotton and infectious bandages etc. in the plant treatment for hazardous waste [8].

\subsubsection{Deep underground burial: -}


The hazardous waste treated in align environment away from wildlife sanctuary, plant and water bodies interaction since during disposal it might cause health disorders and severe environmental effects. The treatment of deep underground burial with the proper coverage such that it does not lead to soil leaching. Since Ranchi is the city of dense population to find the align place for disposal would be difficult, but disposed action could be carried out near the national highway 33.

\subsection{Biomedical waste: -}

In Ranchi, there are ample amount of hospital and clinic, while hospital undergo surgery at regular basis. The survey from one of the reputed hospital shows the usage of least 300 gram used cotton, 260 gram of used bandages, 300-500 grams of infusion kit or injection and above 300 gram of biomolecules of animal depending upon a day and date of surgery these wastes released are covered and separated in different pit since it cannot be exposed to the environment. A common source of biomedical waste is a hospital, clinic, surgeons, dentist, etc. Biomedical can be both in liquid and solid form of garbage. Instances of irresistible waste incorporate disposed of blood, sharps, undesirable microbiological societies and stocks, recognizable body parts (counting those because of removal), other human or creature tissue, utilized wraps and dressings, disposed of gloves, other therapeutic supplies that may have been in contact with blood and body liquids, and research center waste that shows the attributes portrayed previously. Squander sharps incorporate possibly tainted utilized (and unused disposed of) needles, surgical blades, lancets, and different gadgets equipped for infiltrating the skin.

\subsubsection{Autoclaving: -}

Autoclave is a treatment in the pressure chamber requiring raised temperature and pressure. Autoclaves procedure are used in medicinal applications to perform cleansing and by action sterilization to vulcanize provide sterile coating to the material. Modern autoclaves are used in mechanical applications concerning composites. Many autoclaves are utilized to sanitize hardware and supplies by exposing them to pressurized soaked steam at $121^{\circ} \mathrm{C}$ for around $18-20$ minutes relying upon the size of the heap and the substance. In autoclaving with downward air, the use of a vacuum pump to undergo the autoclaving process.

\subsubsection{Chemical Disinfectants: -}

The pathogens, viruses, and bacteria are chemical disinfectants treated by chemical reaction. Chlorine bleach power used to kill pathogens, viruses, and bacteria. Ethylene oxide treatment used for the treatment of chemical disinfectants while microwave radiation used for the treatment of liquid biomedical waste, and it is less expensive compared to incineration.

\section{Conclusion}

The population growth in the city have been increasing since last twenty years. Rapid urbanization and migrating from the villages to the main city for employment and business lead to the increase MSW. The population growth is directly proportional to the generation of MSW. Municipal solid waste is increasing 
with population growth of $2.2 \%$ every year. If the recommendation incorporated in systematic order the environmental mitigation and management standards would substantially increase. The present study shows that Polythene or plastic is $23.93 \%$, bottles $4.7 \%$, clothes $2.9 \%$, metals $2.13 \%$, glass $3.84 \%$, leather $1.28 \%$, grass $0.85 \%$, cow dung $0.85 \%$, ash $1.28 \%$, vegetable peelings $28.205 \%$, syringe, blood cotton and medical tablets $3.84 \%$, construction debris $1.7 \%$, waste food $16.23 \%$, and papers $8.11 \%$ are being generated of total waste. Some of the waste can be converted into energy and then in form of electricity and further can be transferred to the grid. New advanced technologies such as global system for mobile (GSM), Global positioning system (GPS) technology could be used in the waste management process. GSM with application of GPS technology could be locate dustbin and garbage orbit. GSM Technology use the infrared sensor that might help in finding the quality the quantity of the waste for example if the waste is completed filled in dustbin the signal transmitted to vendor such that they could effectively plan waste collection from that particular location. GSM technology could further be optimized to connect different people and to send the notification to the person in charge of waste collection process [9]. The initiative in Mexico City where the people get free Wi-Fi if they dump waste in the dustbin moreover people get extra Wi-Fi if they dumb garbage near the road side area. Similar initiative in Ranchi would create awareness regarding waste disposal and reduction process.

Declaration

Availability of data and materials.

The data is obtained from Census India, and World Bank. While most of the dataset is prepared from the response of the local waste collection vendor and person in charge.

\section{Declarations}

\section{Competing interests}

The authors declare that they have no competing interests including all financial and non-financial interest.

\section{Funding}

Not Applicable

\section{Authors' contributions}

The guidance to carry out this project was supported by Dr. P.K Srivastava and helped to arrange this paper. Major survey was done by Ankish Aman. All authors discussed the results and commented on the manuscript. All authors read and approved the final manuscript. 


\section{Acknowledgements}

Special thanks of gratitude to my teachers who gave opportunity and idea to do this Research. Secondly thanks to the local municipality vendor for helping in survey. I approve that study has been done by Ankish Aman with support of P.K Srivastava and photographs were taken with permission. Study was ethics approved and had consent for this case study.

\section{References}

1. Kumar S, Bhattacharyya JK, Vaidya AN, Chakrabarti T, Devotta S, Akolkar AB. Assessment of the status of municipal solid waste management in metro cities, state capitals, class I cities, and class II towns in India: An insight. Waste Manag. 2009;29:883-95.

2. Parrot L, Sotamenou J, Dia BK. Municipal solid waste management in Africa: Strategies and livelihoods in Yaoundé, Cameroon. Waste Manag. 2009;29:986-95.

3. Memon MA. Integrated solid waste management based on the 3R approach. J Mater Cycle Waste Manag. 2010;12:30-40.

4. Christensen D, Drysdale D, Hansen K, Vanhille J, Wolf A. Partnerships for development: Municipal solid waste management in Kasese, Uganda. Waste Manag Res. 2014;32:1063-72.

5. Kumar A, Pandey AC, Hoda N, Jeyaseelan AT. Evaluation of urban sprawl pattern in the tribaldominated cities of Jharkhand state, India. Int J Remot Sens. 2011;32:7651-75.

6. Judd FK, Jackson HJ, Komiti A, Murray G, Hodgins G, Fraser C. High prevalence disorders in urban and rural communities. Australian New Zealand J Psych. 2002;36:104-13.

7. Marshall RE, Farahbakhsh K. Systems approaches to integrated solid waste management in developing countries. Waste Manag. 2013;33:988-1003.

8. Yusuf AA, Peter O, Hassan AS, Tunji LA, Oyagbola IA, Mustafa MM, Yusuf, et al. Municipality solid waste management system for Mukono District. Uganda Procedia Manufacturing. 2019;35:613-22.

9. He P, Chen L, Shao L, Zhang H, Lü F. Municipal solid waste (MSW) landfill: A source of microplastics? -Evidence of microplastics in landfill leachate. Water Res. 2019;159:38-45.

10. Ong YH, Chua AS, Huang YT, Ngoh GC, You SJ. The microbial community in a high-temperature enhanced biological phosphorus removal (EBPR) process. Sustainable Environment Research. 2016;26(1):14-9.

\section{Figures}




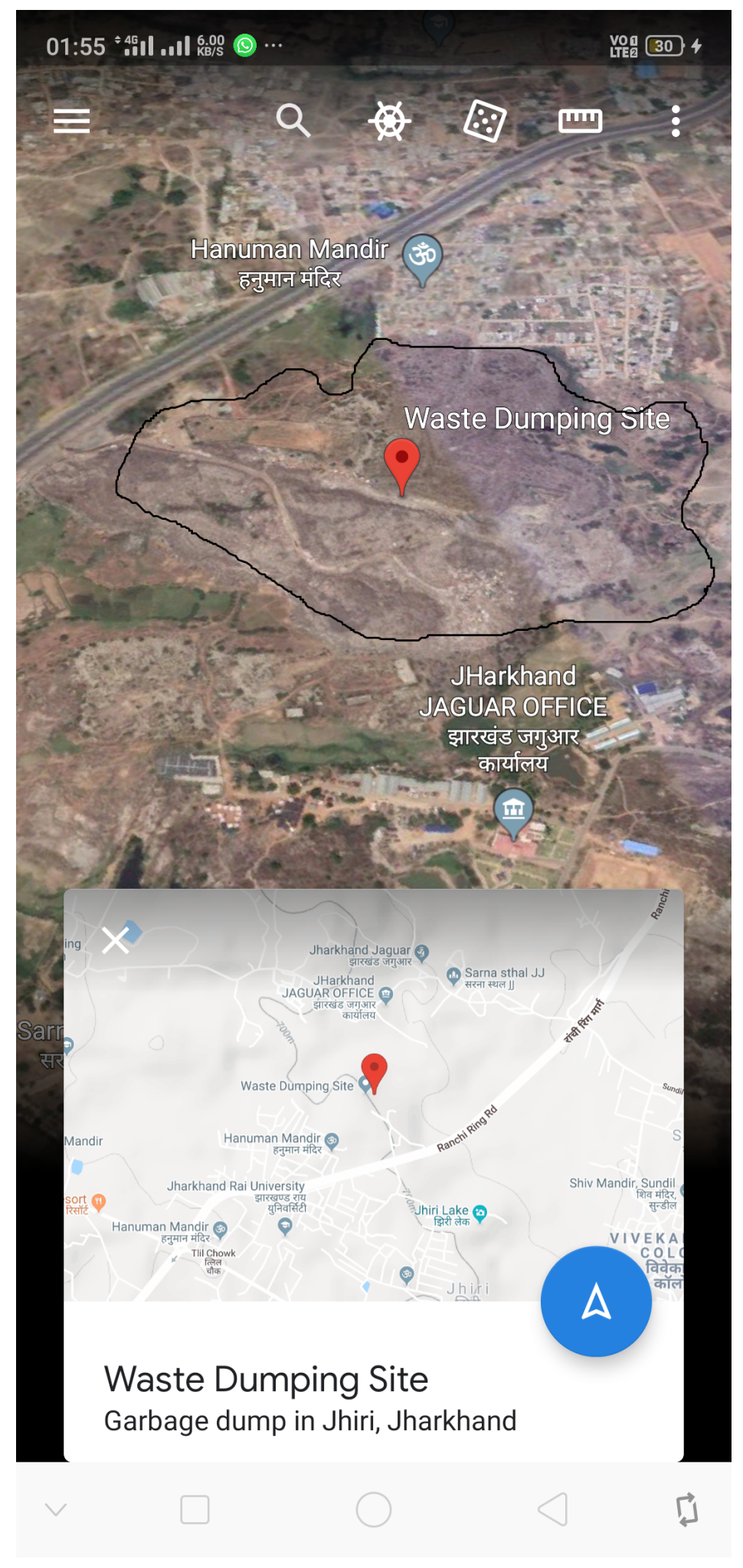

Figure 1 


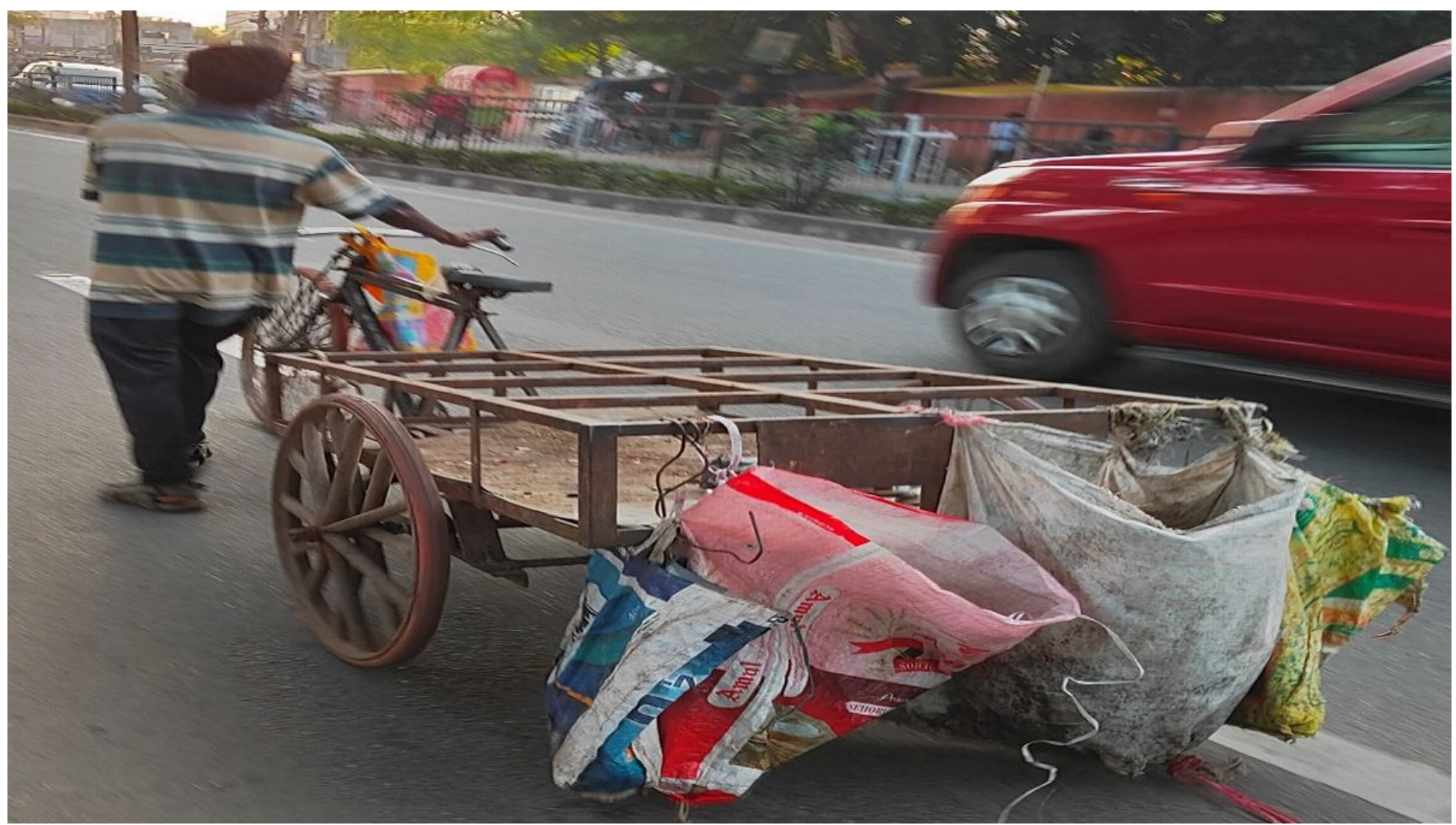

Figure 2 




Figure 3 


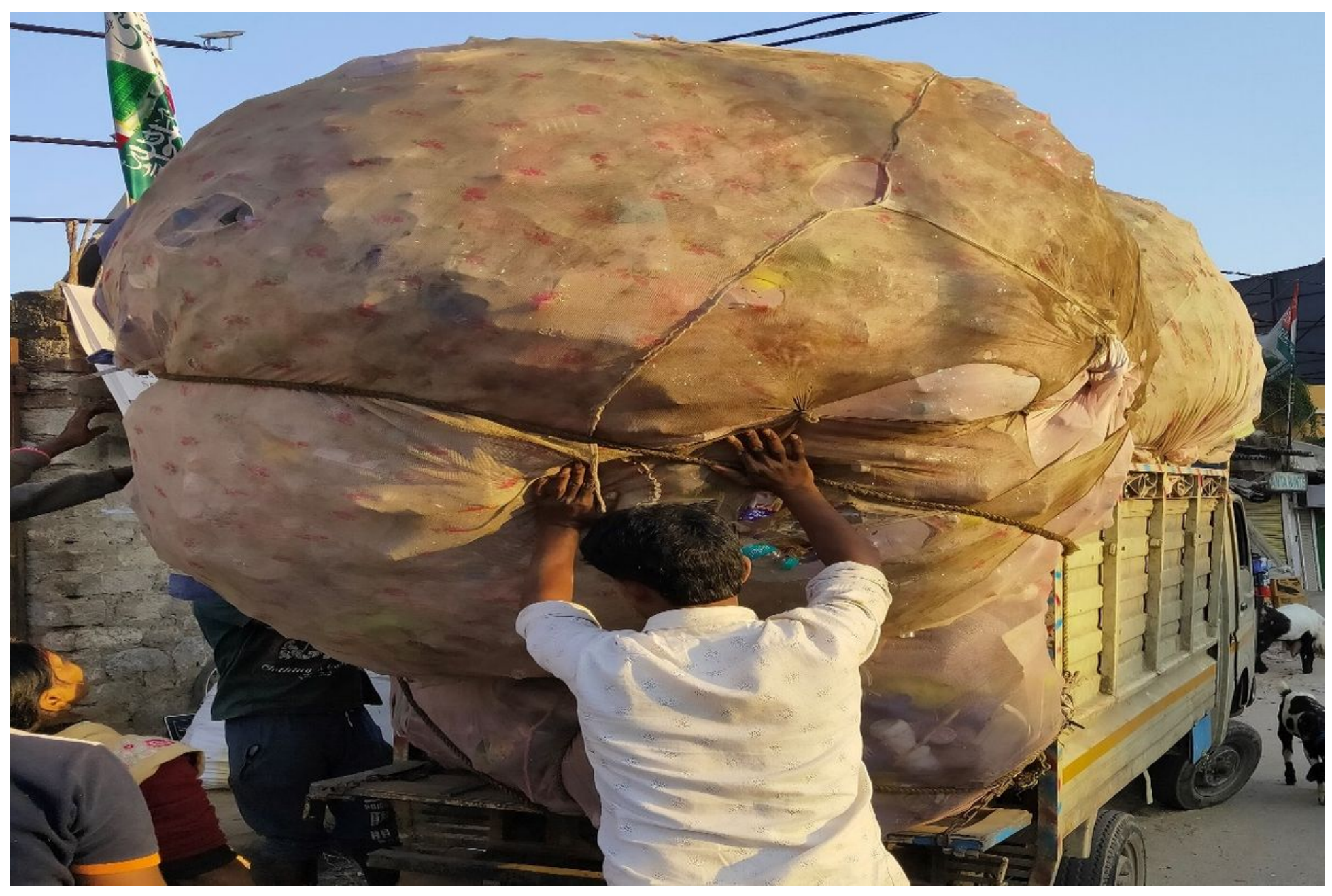

Figure 4 


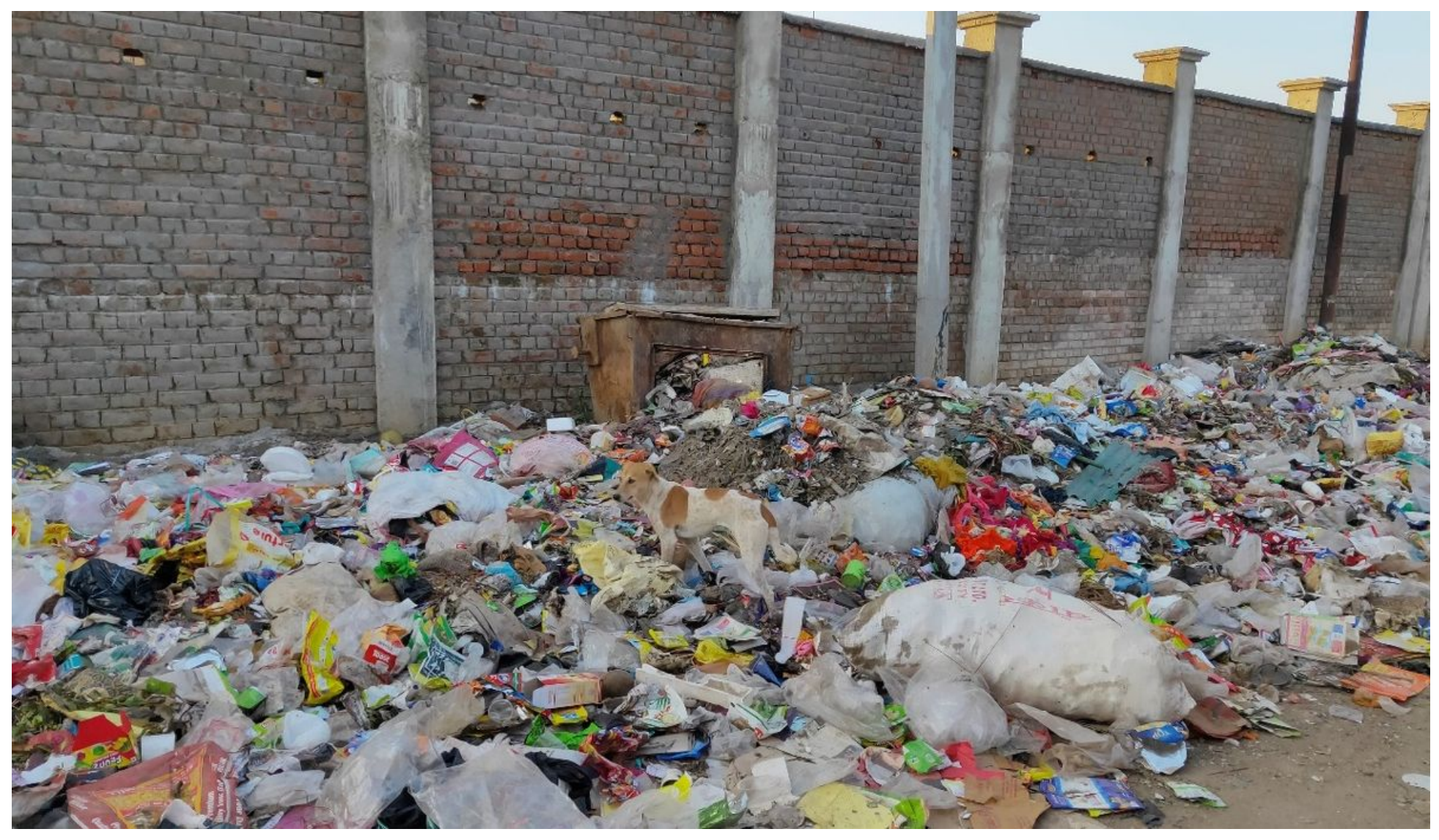

\section{Figure 5}



Figure 6 


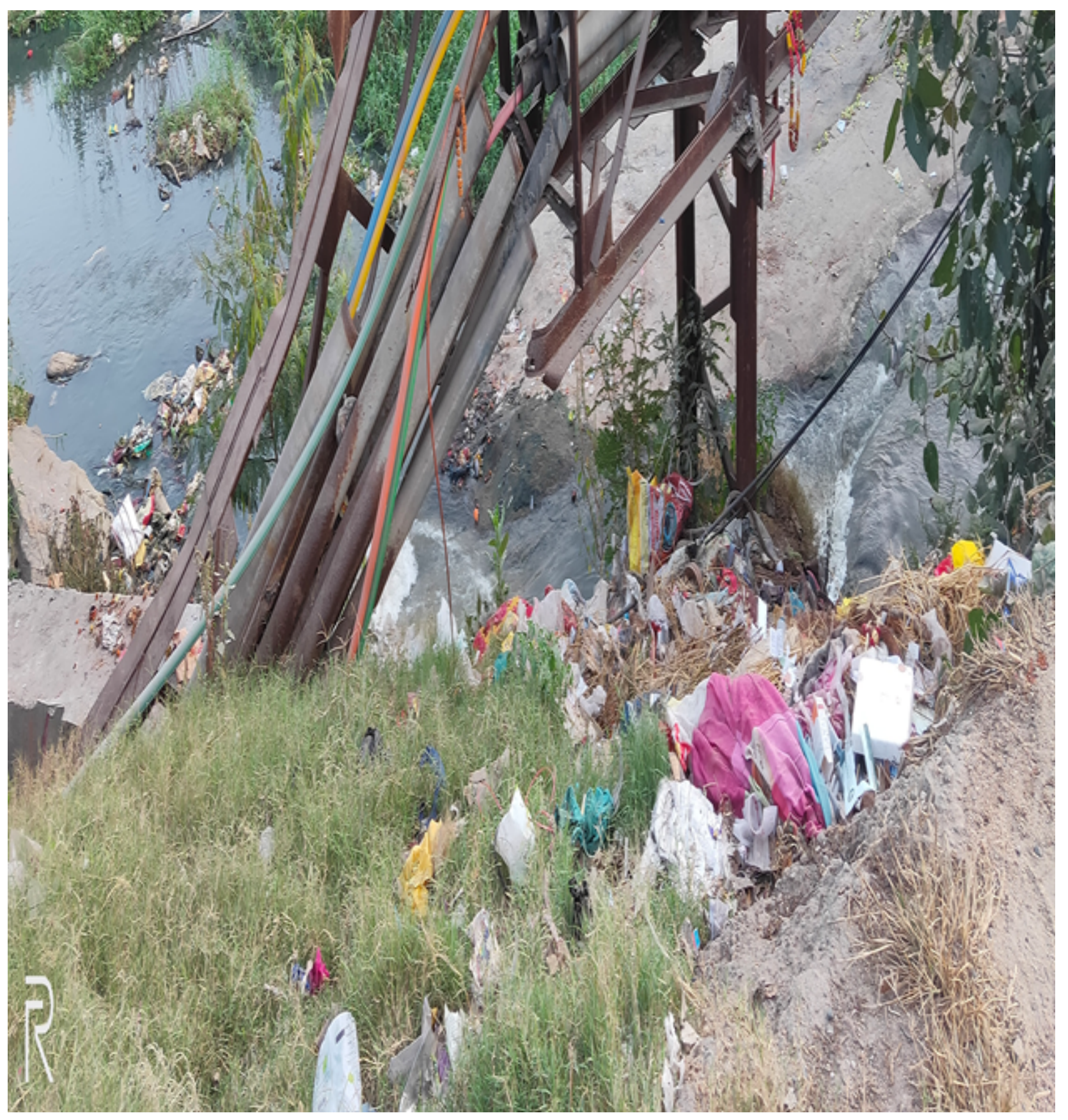

Figure 7 


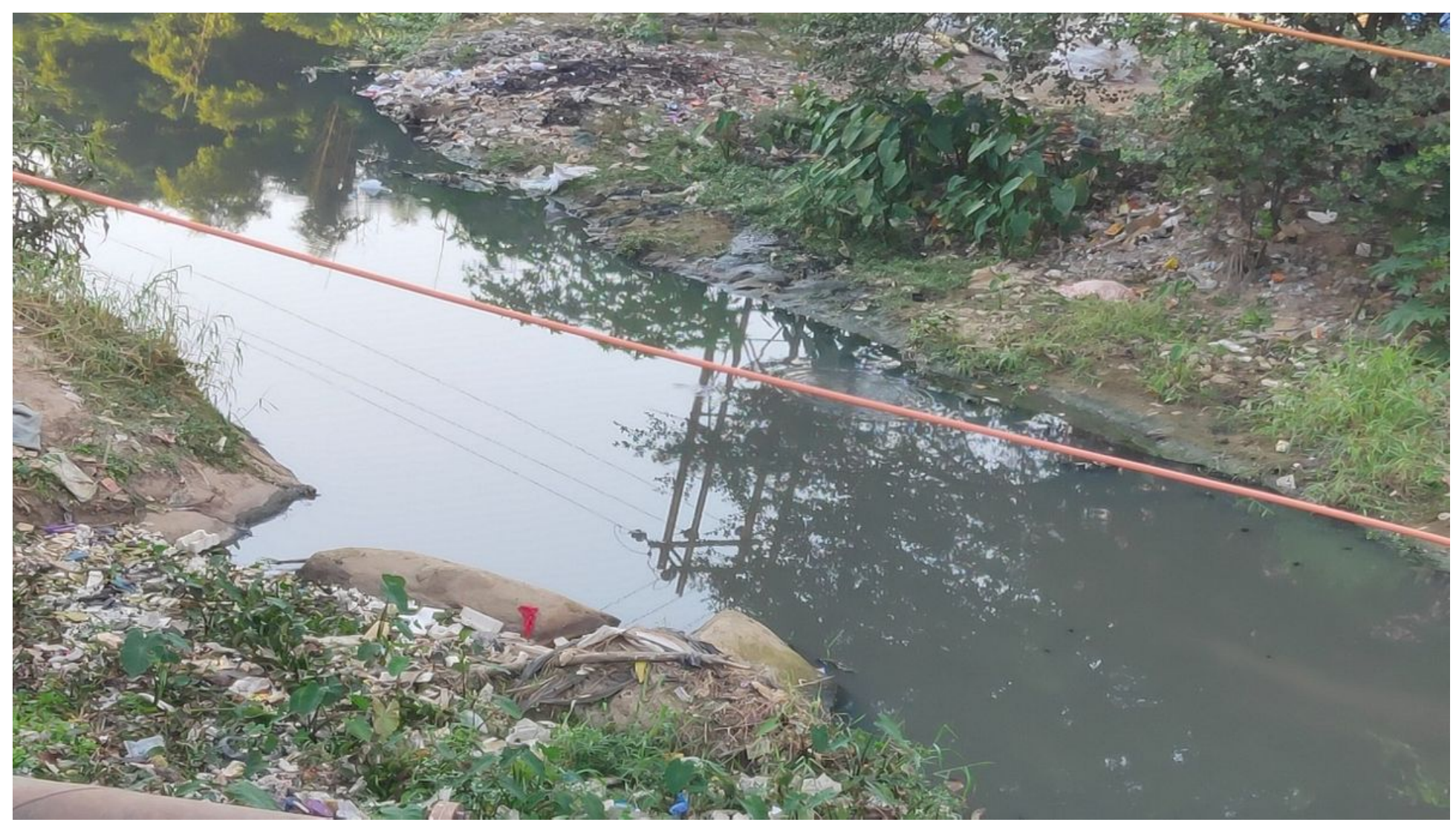

\section{Figure 8}

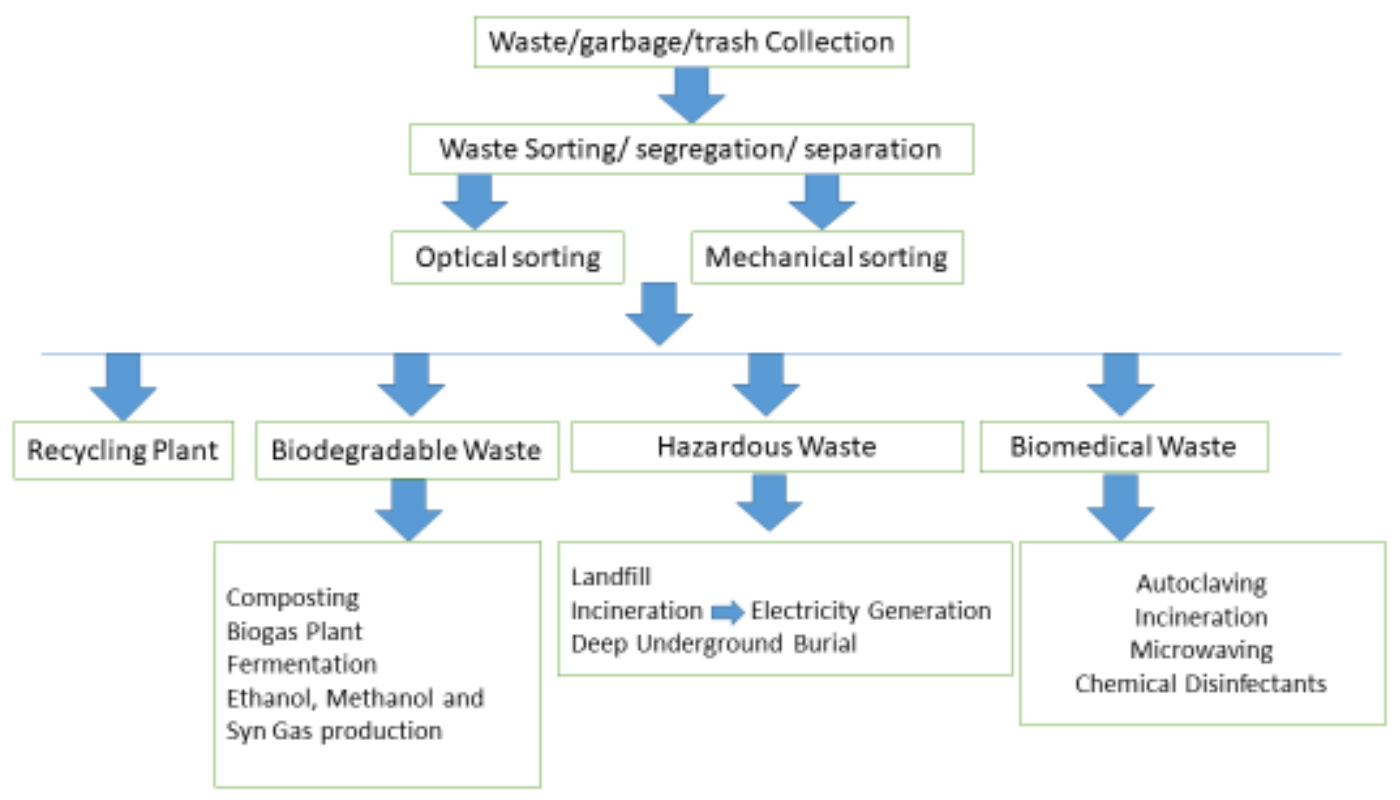

Figure 9 


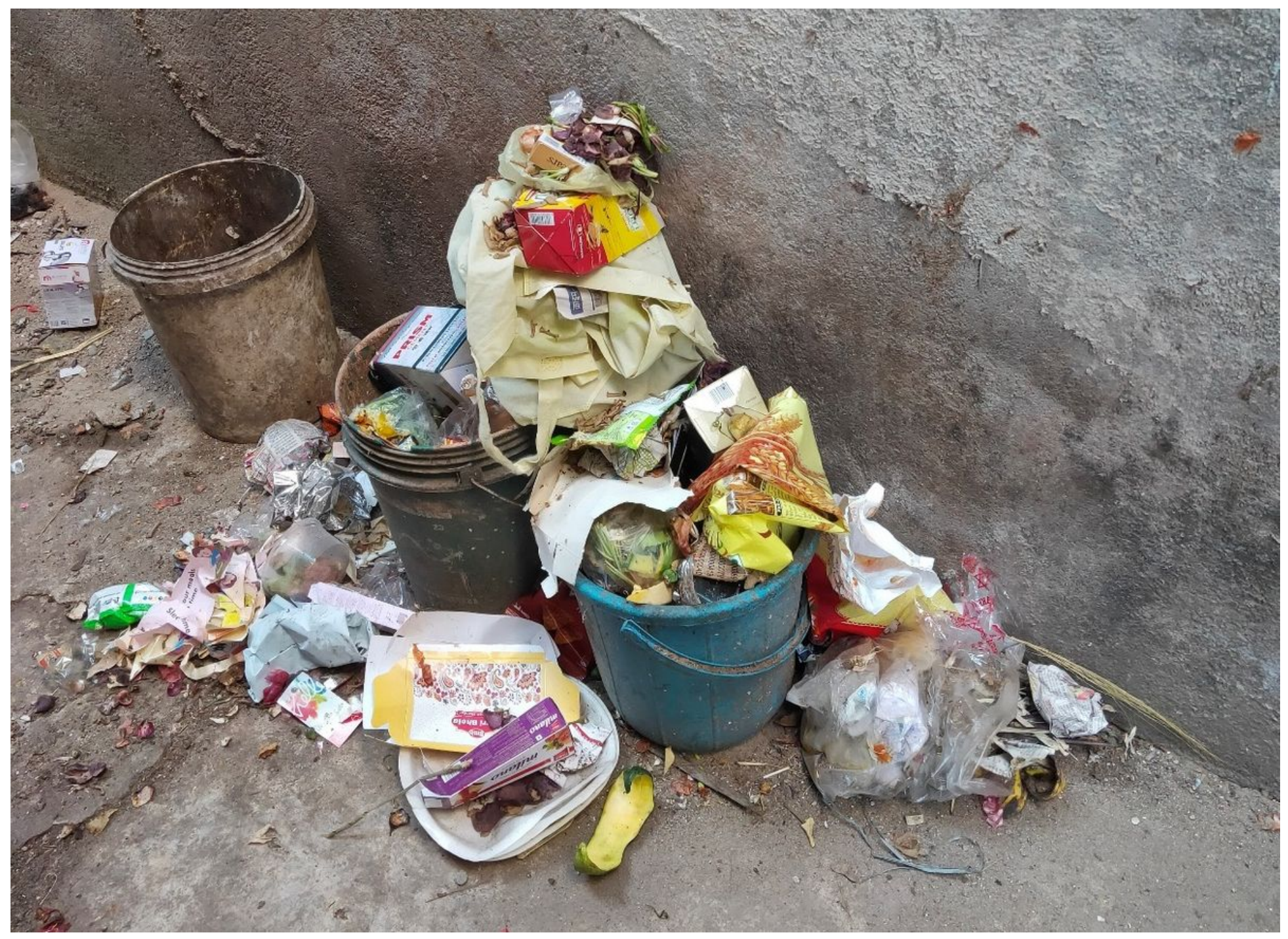

Figure 10 


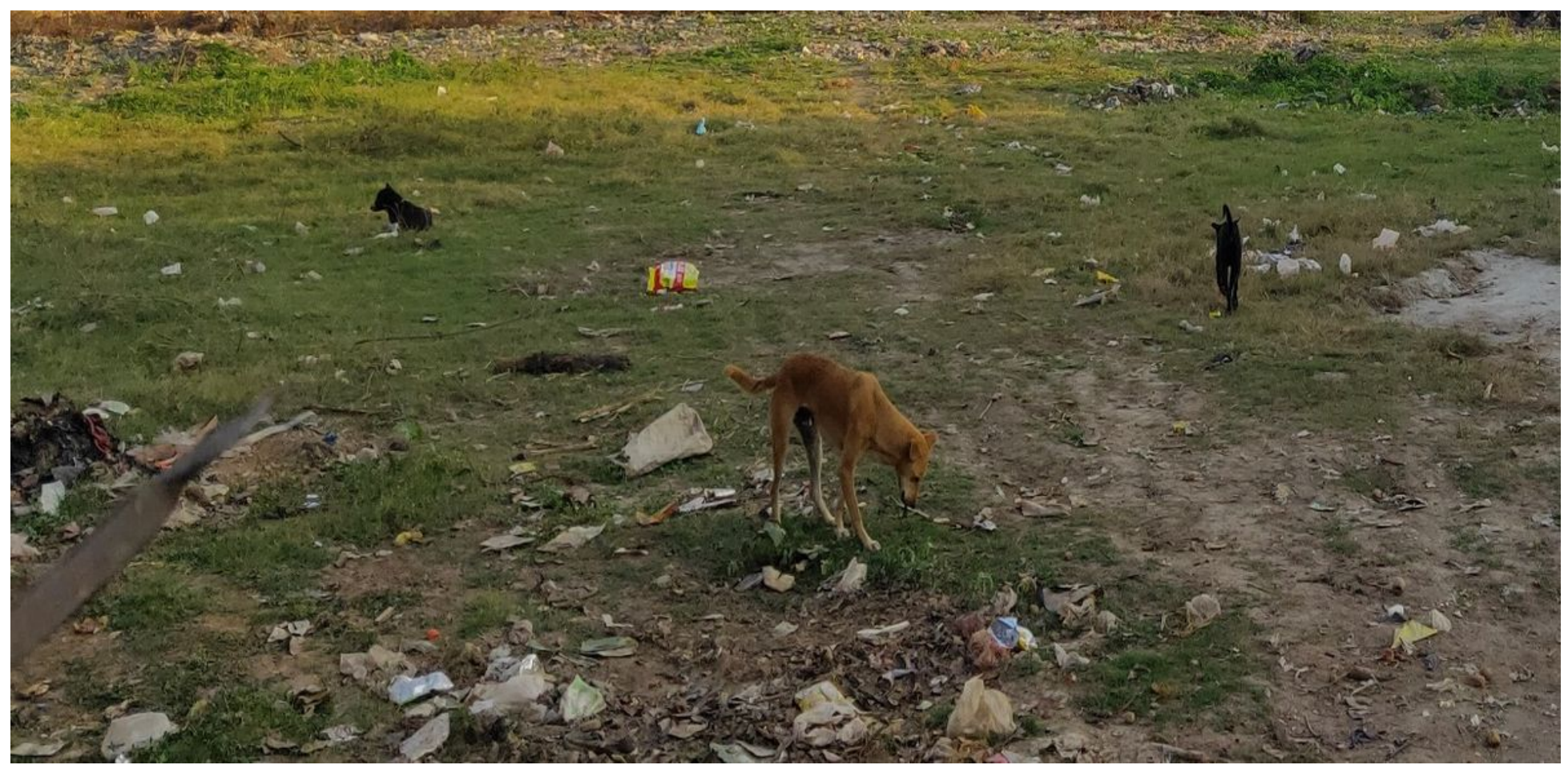

Figure 11 


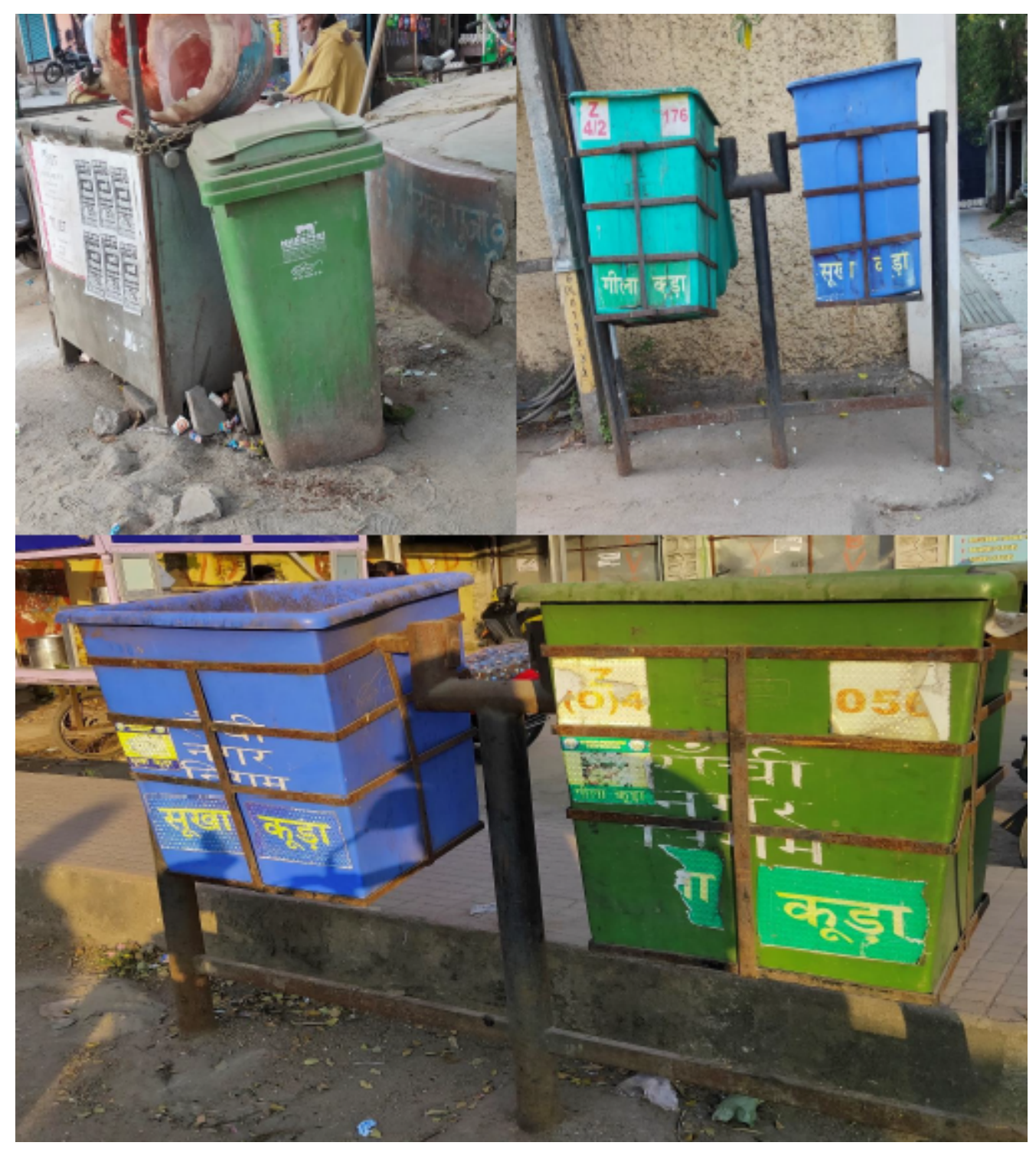

Figure 12 


\section{Physical Composition Percentage}

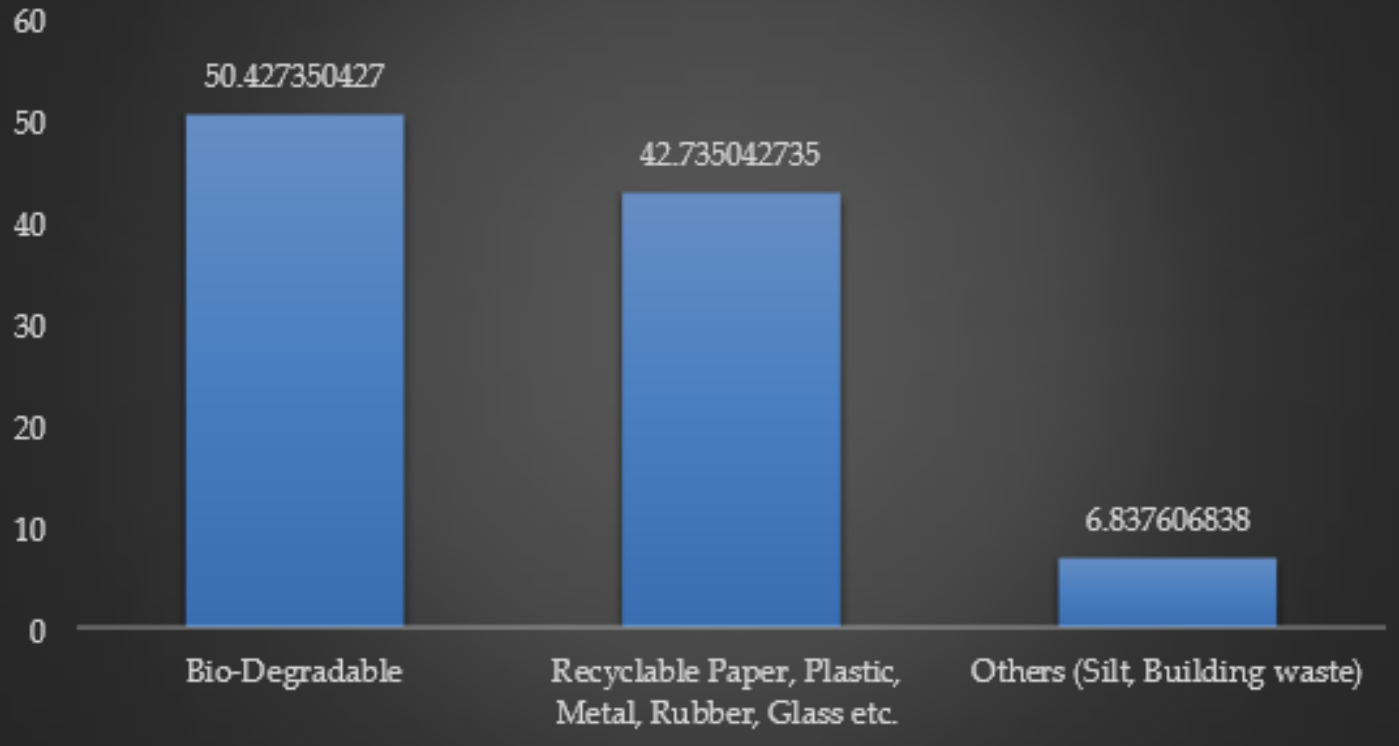

Figure 13

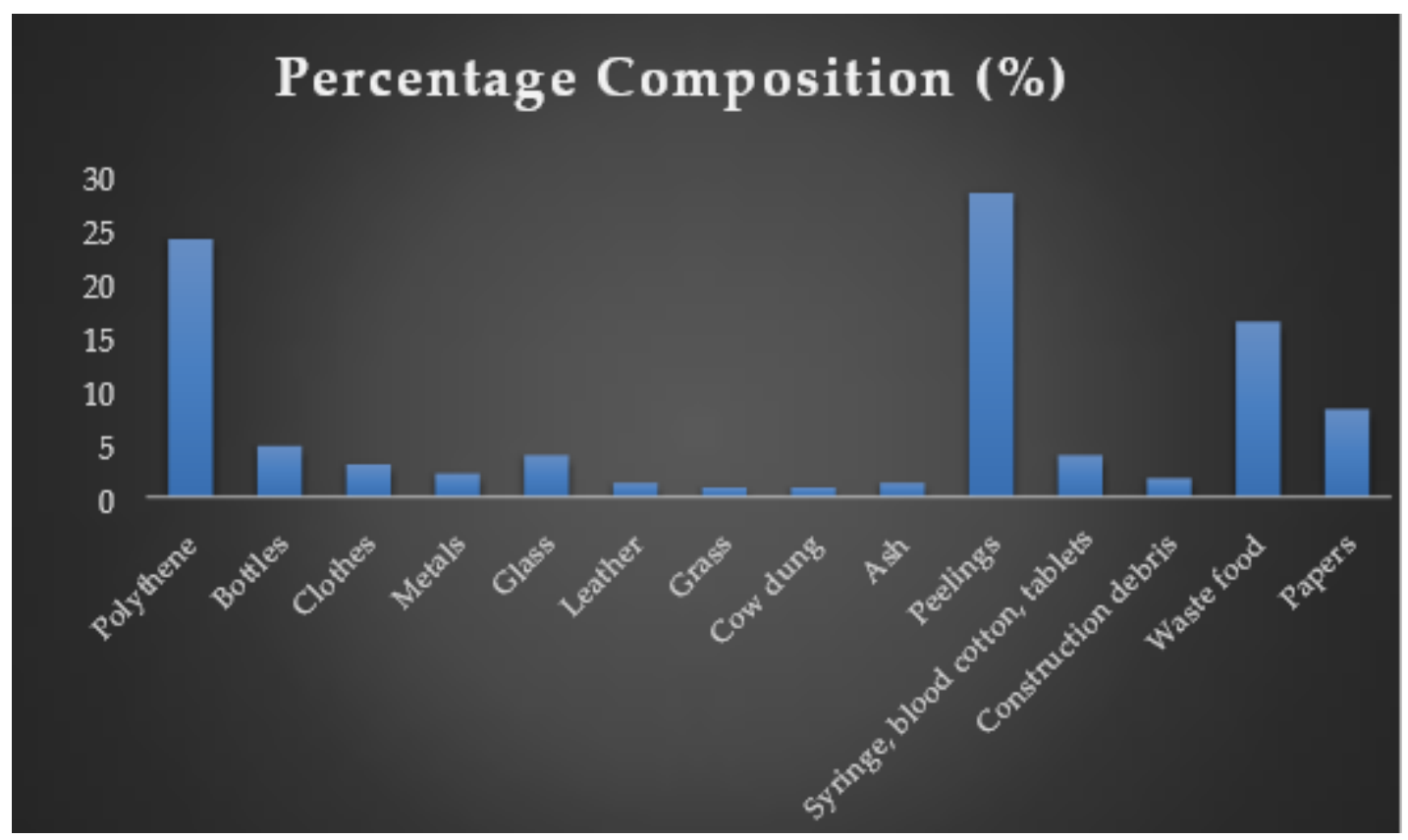

Figure 14 